\title{
ANALISIS PENGARUH TINGKAT SUKU BUNGA SBI DAN VOLUME EKSPOR IMPOR TERHADAP NILAI TUKAR RUPIAH
}

\author{
Oleh: \\ Andy El Yudha \\ Alumni Fakultas Ekonomi Universitas Muhammadiyah Malang \\ E-mail/No. Hp: - /0355371076 \\ Syamsul Hadi \\ Fakultas Ekonomi Universitas Muhammadiyah Malang \\ E-mail/No. Hp: - /08885156969
}

\begin{abstract}
The purpose of this research is to know the level of effect interest rate and volume export import to year rupiah exchange rate 2002-2006. In this research, the auther taken hypothesis which guesses that interest rate, value export import, rupiah exchange rate to \$ US Lag_1 has significant effect to rupiah exchange rate. Technique analyse the data by writer by using doubled linear analysis regresi with the ordinary smallest square (OLS) and also use the test $t$ and test F. From the analysis can be pulled conclusion that variable interest rate and export import volume have negative effect to rupiah exchange rate, while variable rupiah exchange rate to \$ US Lag_l have positive and significant to rupiah exchange rate.
\end{abstract}

Keywords : exchange rate, Interest Rate, Export Import

\section{PENDAHULUAN}

Sektor perdagangan luar negeri menjadi penghubung antara perekonomian dalam negeri dengan perekonomian luar negeri. Hubungan tersebut menyebabkan adanya saling ketergantungan di antara berbagai perekonomian. Oleh karena itu, semakin terbuka perekonomian suatu negara, semakin pekalah kesejahteraannya terhadap kegiatan ekonomi yang terjadi di tempat lain.

Kecenderungan dunia yang semakin mengglobal akan menyebabkan perekonomian suatu negara semakin terintegrasi dengan perekonomian dunia, sesuai dengan kadar keterbukaan negara yang bersangkutan. Demikian pula yang terjadi di Indonesia. Akibat perekonomian yang semakin terbuka menyebabkan perekonomian Indonesia semakin banyak dipengaruhi oleh kondisi perekonomian dunia. Derajat keterbukaan tersebut akan membawa dampak pada perubahan nilai tukar.

Seperti halnya negara lain, Indonesia dalam melakukan perdagangan internasional memerlukan devisa (foreign exchange) berupa mata uang kuat (hard currency) yaitu mata uang yang bisa diterima secara luas sebagai bukti pembayaran internasional dan digunakan sebagai alat tukar dalam transaksi internasional (Kuncoro, 1996:18). Mata uang yang tergolong dalam kategori tersebut adalah Dolar AS, Poundsterling, Yen dan Deutsche Mark. Oleh karena itu penting untuk mengetahui nilai tukar (exchange rate) 
valuta asing dalam perdagangan internasional.

Pada dasarnya jenis sistem nilai tukar yang utama meliputi, pertama, nilai tukar mengambang (floating exchange rate) yang terdiri dari: mengambang bebas (clean floating rates) ditentukan oleh mekanisme pasar tanpa campur tangan pemerintah dan mengambang terkendali (dirty floating rates), ada campur tangan pemerintah. Kedua, sistem nilai tukar tertambat (pegged exchange rates) yaitu menambatkan nilai mata uangnya dengan mata uang lain atau sekelompok mata uang. Ketiga, sistem tertambat merangkak (crawling pegs) yaitu melakukan sedikit perubahan dalam nilai mata uangnya secara periodik dengan tujuan untuk bergerak menuju suatu nilai tertentu pada rentang waktu tertentu. Keempat, sekeranjang mata uang (basket of currencies), menetapkan nilai mata uangnya berdasarkan sekeranjang mata uang. Kelima, nilai tukar tetap (fixed exchange rates) yaitu negara mengumumkan suatu nilai tukar tertentu atas mata uangnya dan menjaga nilai tukar ini dengan menyetujui untuk membeli atau menjual valas dalam jumlah tak terbatas pada nilai tukar tersebut (Kuncoro,1996:27).

Di Indonesia, ada tiga sistem yang digunakan dalam kebijakan nilai tukar rupiah sejak tahun 1971 hingga sekarang. Antara tahun 1971 hingga 1978 dianut sistem tukar tetap (fixed exchange rate) dimana nilai rupiah secara langsung dikaitkan dengan dolar Amerika Serikat (USD). Sejak 15 November 1978 sistem nilai tukar diubah manjadi mengambang terkendali (managed floating exchange rate) dimana nilai rupiah tidak lagi sematamata dikaitkan dengan USD. Maksud dari sistem nilai tukar tersebut adalah bahwa meskipun diarahkan ke sistem nilai tukar mengambang namun tetap menitik beratkan unsur pengendalian.
Kemudian terjadi perubahan mendasar dalam kebijakan mengambang terkendali terjadi pada tanggal 14 Agustus 1997, dimana jika sebelumnya Bank Indonesia menggunakan band sebagai guidance atas pergerakan nilai tukar maka sejak saat itu tidak ada lagi band sebagai acuan nilai tukar.

Namun demikian cukup sulit menjawab apakah nilai tukar rupiah sepenuhnya dilepas ke pasar (free floating) atau masih akan dilakukan intervensi oleh Bank Indonesia. Dengan mengamati segala dampak dari sistem free floating serta dikaitkan dengan kondisi/struktur perekonomian Indonesia selama ini nampaknya purely free floating sulit untuk dilakukan. Kemungkinannya adalah Bank Indonesia akan tetap mempertahankan managed floating dengan melakukan intervensi secara berkala, selektif, dan pada timing yang tepat.

Dengan diberlakukannya sistem nilai tukar mengambang penuh/bebas (freely floating system) yang dimulai sejak Agustus 1997, posisi nilai tukar rupiah terhadap mata uang asing (khususnya US\$) ditentukan oleh mekanisme pasar. Sejak masa itu naik turunnya nilai tukar (fluktuasi) ditentukan oleh kekuatan pasar.

Pergerakan nilai tukar rupiah terhadap USD pasca diberlakukannya sistem nilai tukar mengambang terus mengalami kemerosotan. Pada bulan Agustus 1997 nilai tukar rupiah terhadap USD sebesar Rp 3.035,-per USD, terus mengalami tekanan sehingga pada Desember 1997 nilai tukar rupiah terhadap USD tercatat sebesar Rp 4.650,-per USD. Memasuki tahun 1998, nilai tukar rupiah melemah menjadi sebesar Rp10.375,-per USD, bahkan pada bulan Juni 1998 nilai tukar rupiah sempat menembus level Rp14.900,-per USD yang merupakan nilai tukar terlemah sepanjang sejarah nilai tukar 
rupiah terhadap USD. Nilai tukar rupiah terhadap USD tahun 1999 melakukan recovery menjadi sebesar $\mathrm{Rp} 7.810$,-per USD, tahun 2000 kembali melemah sebesar Rp 8.530,-per USD, tahun 2001 melemah lagi menjadi Rp10.265,- per USD, tahun 2002 kembali menguat menjadi Rp 9.260,-per USD, tahun 2003 menguat menjadi Rp8.570,-per USD dan pada tahun 2004 sebesar Rp 9.400,-per USD.

Pada tahun 2005, melambungnya harga minyak dunia yang sempat menembus level USD 70/barrel memberikan kontribusi yang cukup besar terhadap meningkatnya permintaan valuta asing sebagai konsekuensi negara pengimpor minyak. Kondisi ini menyebabkan nilai tukar rupiah melemah terhadap US\$ dan rata-rata kurs rupiah pada tahun 2005 mencapai Rp 9.705,- per USD.

Memasuki tahun 2006 nilai tukar rupiah menguat antara lain didorong oleh arus masuk modal asing melalui SBI, SUN, dan pasar modal; serta menurunnya kebutuhan impor. Dalam bulan April 2006, rata-rata harian nilai tukar rupiah mencapai Rp 8.937,-per USD dan dalam empat bulan pertama tahun 2006 mencapai Rp 9.212,-per USD.

Di tahun 2007 ekonomi Indonesia mengalami perkembangan amat pesat dalam satu dekade terakhir. Bank Dunia dalam laporan terbarunya, memuji keberhasilan Indonesia dalam sektor fiskal dan arah kebijakan pemerintah di bidang makro ekonomi. Hal ini disampaikan oleh Wakil Presiden Bank Dunia untuk Asia Timur dan Pasifik, Jim Adams (Republika, 12 Juli 2007).

Keberhasilan makro ekonomi Indonesia saat ini memang mengesankan. Hal ini tercermin antara lain lewat penurunan BI rate dari 12,75 persen tahun 2006 menjadi 8,25 persen pada Juli 2007. Nilai tukar rupiahpun juga bergerak stabil pada Rp 9.000-9.200 per satu dolar AS. Keberhasilan lain yang dicapai adalah indeks harga saham di Bursa Efek Jakarta yang mencatat kinerja terbaik ketiga di Asia, dan nilai ekspor Indonesia yang terus meningkat.

Bagi Indonesia dalam upaya membangun perekonomian yang lebih baik, harus didahului upaya untuk menentukan nilai tukar valuta asing pada tingkat yang menguntungkan sehingga momentum pembangunan menjadi sehat dan kegairahan dunia usaha yang berada pada tingkat yang tinggi tetap dapat terpelihara. Namun kesemuanya itu tidaklah mudah dan memerlukan perhatian yang besar. Faktor-faktor yang mempengaruhi nilai tukar sangat beragam sehingga perlu diketahui bagaimana perilaku nilai tukar dalam jangka pendek dan jangka panjang, sehingga memudahkan pemerintah dalam menerapkan kebijaksanaan pengendalian nilai tukar. Penentuan nilai tukar valuta asing menjadi pertimbangan penting bagi negara yang terlibat dalam perdagangan internasional karena nilai tukar valuta asing berpengaruh besar terhadap biaya dan manfaat dalam perdagangan internasional.

Fluktuasi yang dialami oleh nilai tukar rupiah akan berpengaruh pada aktifitas ekspor dan impor dan sebaliknya perubahan pada aktifitas tersebut juga bisa mempengaruhi nilai tukar rupiah. Maka, melalui sektor luar negeri tersebut akan dimulai proses kontaminasi perekonomian domestik oleh perekonomian luar negeri.

Daya tarik dari hubungan antara nilai tukar dan tingkat harga terletak pada perbedaan pandangan antar beberapa ekonom mengenai faktorfaktor yang mempengaruhi nilai tukar. Satu sisi menganggap bahwa faktor penting yang mempengaruhi nilai tukar adalah jumlah uang beredar, tingkat 
output riil dan suku bunga (Mac Donald and Taylor, 1994).

Pendekatan yang digunakan untuk mengetahui faktor-faktor yang mempengaruhi nilai tukar adalah pendekatan perdagangan dan pendekatan paritas daya beli. Model pendekatan perdagangan ini melihat bahwa nilai tukar/kurs antara dua mata uang dari dua negara ditentukan oleh besar kecilnya perdagangan barang dan jasa diantara kedua negara tersebut. Menurut pendekatan ini kurs ekuilibrium adalah kurs yang akan menyeimbangkan nilai impor dan ekspor dari suatu negara. Jika nilai impor negara tersebut lebih besar dari pada nilai ekspornya (artinya negara bersangkutan mengalami defisit perdagangan), maka kurs mata uangnya mengalami peningkatan (artinya mata uang tersebut mengalami depresiasi/penurunan nilia tukar) (Salvatore, 1997:43).

Sedangkan pendekatan paritas daya beli (purchasing power parity) secara garis besar menyatakan bahwa pasar valuta asing berada dalam kondisi keseimbangan apabila semua deposito/tabungan simpanan dalam berbagai valuta asing menawarkan tingkat tingkat imbalan yang sama. Kurs ekuilibrium tercipta apabila terjadi kondisi paritas suku bunga (interest parity), dimana hal ini menyatakan bahwa dalam sistem devisa bebas tingkat bunga dinegara satu akan cenderung sama dengan tingkat bunga dinegara lain, setelah diperhitungkan mengenai laju depresiasi mata uang negara satu terhadap yang lain (Boediono,1995:101). Berdasarkan latar belakang permasalahan yang ada, maka dapat dirumuskan masalah 1) Apakah nilai tukar rupiah terhadap dolar dipengaruhi oleh tingkat suku bunga SBI, volume ekspor-impor? 2)Seberapa besar pengaruh masing-masing variabel terhadap nilai tukar mata uang rupiah terhadap dolar AS?

\section{TINJAUAN PUSTAKA}

Secara sederhana, kurs mata uang adalah perbandingan nilai antar mata uang. Kurs menunjukkan harga suatu mata uang jika dipertukarkan dengan mata uang lain. Sebagai contoh, nilai kurs rupiah per US\$ sebesar Rp 10.000/US\$, berarti bahwa untuk membeli US\$ 1 diperlukan Rp 10.000. Sebaliknya, untuk memperoleh $\mathrm{Rp} 1$ dibutuhkan US\$ 0.0001 .

Meskipun sering dipadankan, pada dasarnya istilah "nilai tukar mata uang" dan "kurs" tidaklah sama, melainkan berbanding terbalik, sebagai contoh, jika semula nilai US\$1 sama dengan $\mathrm{Rp}$ 9.800 kemudian menjadi US\$1 sama dengan $\mathrm{Rp}$ 10.000, maka kurs rupiah naik karena angkanya semakin besar namun nilai tukarnya turun, sebaliknya kurs dolar turun namun nilai tukarnya naik (Salvatore, 1997:9).

Setiap negara memiliki sebuah mata uang yang menunjukkan harga barang dan jasa. Kurs memberi peranan sentral dalam perdagangan internasional untuk membandingkan segenap barang dan jasa yang dihasilkan oleh berbagai negara. Nilai tukar menurut Rivers Batiz (1994) adalah harga dimana mata uang asing dapat dijual dan dinyatakan dalam satuan mata uang domestik dan harus ditentukan berdasarkan kekuatan permintaan dan penawaran, dimana nilai tukar fungsinya memperbolehkan pembeli dan penjual mata uang untuk mempertukarkan satu mata uang ke mata uang lainya. Sedangkan menurut Lipsey (1990) nilai tukar adalah harga dimana pembelian dan penjualan atas mata uang asing atau klaim terjadi dan jumlah mata uang domestik yang harus dibayarkan untuk memperoleh satu unit mata uang asing. 
Kurs mata uang berfluktuasi setiap saat. Dalam sistem mata uang mengambang bebas (free float), apabila harga suatu mata uang menjadi semakin mahal terhadap mata uang lain, maka mata uang itu dikatakan terapresiasi. Sebaliknya, jika harga suatu mata uang turun terhadap mata uang lain, mata uang itu disebut terdepresiasi. Dalam sistem mata uang tertambat (pagged), kenaikan nilai suatu mata uang terhadap mata uang lain disebut revaluasi, sedangkan penurunan nilai suatu mata uang disebut devaluasi.

Nilai tukar suatu mata uang memiliki dua konsep yaitu: pertama konsep nominal adalah merupakan konsep untuk mengukur harga mata uang yang berbeda, dimana konsep ini menyatakan berapa jumlah mata uang suatu negara yang diperlukan untuk mendapatkan sejumlah mata uang asing. Kedua, konsep riil adalah konsep yang mengukur perbedaan harga dari suatu komoditi ekspor suatu negara di pasar internasional, sedangkan komponen nominal adalah perkembangan kurs mata uang asing baik bilateral maupun multilateral sehingga nilai tukar riil suatu mata uang dapat berfluktuasi tetapi nilai tukar nominal stabil.

Nilai tukar nominal dibedakan ada dua yaitu: nilai tukar spot dan nilai tukar forward. Nilai tukar spot adalah nilai tukar dimana penyerahan barang dilaksanakan bersamaan pada saat transaksi terjadi. Sedangakan Nilau tukar forward adalah nilai tukar dimana penyerahan barang dilakukan dikemudian hari setelah transaksi terjadi.

Untuk melihat hubungan diantara kurs riil dan kurs nominal, sebagai contoh sebuah barang yang diproduksi di banyak negara: mobil. Jika harga mobil Amerika adalah $\$ 10.000$ dan harga mobil Jepang 2.400.000 yen. Untuk membandingkan harga kedua mobil tersebut, harus mengubahnya menjadi mata uang umum. Jika satu dolar bernilai 120 yen, maka harga mobil Amerika adalah 1.200.000 yen. Membandingkan harga mobil Amerika (1.200.000 yen) dan harga mobil Jepang (2.400.000 yen), dapat disimpulkan bahwa harga mobil Amerika separuh dari harga mobil Jepang. Dengan kata lain, pada harga berlaku, kita bisa menukar 2 mobil Amerika untuk 1 mobil jepang.

$$
\begin{aligned}
\text { Kurs Riil } & =\frac{(12 \text { yen } / \text { dolar }) \times(10.000 \text { dolar } / \text { Mobil Amerika })}{(2.400 .000 \text { yen } / \text { Mobil Jepang })} \\
& =0,5 \times \frac{\text { Mobil Jepang }}{\text { Mobil Amerika }}
\end{aligned}
$$

Pada harga dan kurs ini, kita dapatkan separuh harga mobil Jepang per mobil Amerika. Secara umum perhitungan ini dapat ditulis:

$$
\text { Kurs Riil }=\frac{\text { (Kurs Nominal) } \mathrm{x} \text { Harga Barang Domestik }}{\text { (Harga Barang Luar Neger } i)}
$$

Tingkat dimana kita memperdagangkan barang domestik dan barang luar negeri tergantung pada harga barang dalam mata uang lokal pada tingkat dimana mata uang dipertukarkan.

Perhitungan kurs riil untuk barang tunggal ini menjelaskan bagaimana kita seharusnya mendefinisikan kurs riil untuk kelompok barang yang lebih luas. Dimana e sebagai kurs nominal (jumlah yen per dolar), $\mathrm{P}$ adalah tingkat harga di Amerika Serikat (diukur dalam dolar), dan $\mathrm{P}^{*}$ adalah tingkat harga di jepang (diukur dalam yen) Maka kurs riil $\varepsilon$ adalah:

Kurs Riil $=$ Kurs Nominal $\mathrm{x}$ Rasio Tingkat Harga

$$
\varepsilon=\mathrm{e} \quad \mathrm{x}\left(\mathrm{P} / \mathrm{P}^{*}\right)
$$

Kurs Riil diantara kedua negara dihitung dari kurs nominal dan tingkat harga di kedua negara. Jika kurs Riil adalah tinggi, barang-barang luar negeri relatif murah, dan barang-barang domestik relatif mahal. Jika Kurs riil adalah rendah, barang-barang luar negeri relatif mahal, barang-barang domestik relatif murah (Mankiw,2000:192-193). 
Tingkat bunga dalam pengertian dasar adalah harga dari penggunaan uang untuk jangka waktu tertentu. Tingkat bunga sebagai harga yang harus dibayar apabila terjadi pertukaran antara satu rupiah sekarang dan satu rupiah yang akan datang. Menurut Keynes tingkat suku bunga ditentukan oleh Preferensi Likuiditas (Likuidity Preference) dan jumlah uang. Sedangkan Likuidity Preference disebabkan oleh:

Transaction Motive, dimana orang memerlukan uang yang likuid untuk melakukan transaksi pembayaran seharihari.

Precautionary Motive, dimana orang ingin mempunyai persediaan uang untuk menghadapi peristiwa yang tidak terduga, cadangan/persediaan bila sewaktu-waktu harus melakukan pembayaran.

Speculative Motive, dimana orang ingin mempunyai uang likuid untuk mencari untung pada saat dapat dilakukan spekulasi.

Kaum klasik berpendapat bunga adalah harga dari penggunaan dana yang dipinjam, yang berarti dana yang terjadi untuk dipinjamkan/harga yang terjadi dipasar dana investasi. Dana yang dipinjamkan dibentuk oleh penabung yang berfungsi sebagai suplai dan investor yang berfungsi sebagai demand. Penabung yaitu anggota masyarakat yang menerima pendapatan melebihi apa yang mereka perlukan untuk kebutuhan konsumsinya selama periode tertentu. Sedangkan investor adalah anggota masyarakat yang membutuhkan dana. Akibat adanya permintaan dan penawaran akan dana maka terjadilah pasar Leonable yang mempertumukan penabung dan investor. Dan dari proses tawar-menawar antara mereka akhirnya dihasilkan tingkat suku bunga keseimbangan (Boediono.1995:77).

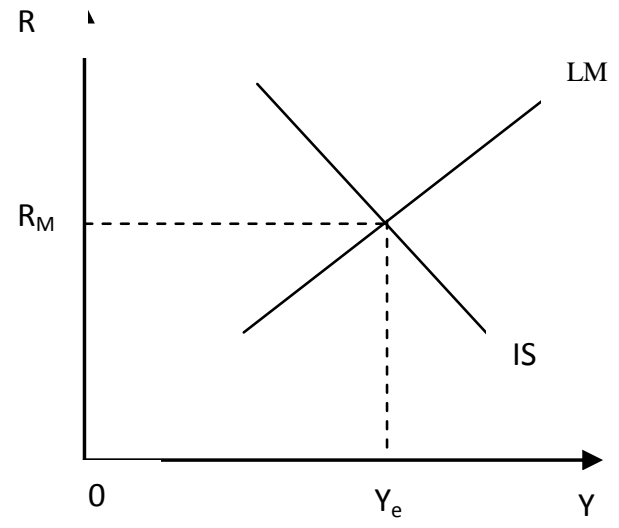

Gambar 1. Terjadinya Tingkat Bunga Keseimbangan (Sumber: Nopirin, 1983:98-100)

Tingkat bunga akan naik apabila jumlah uang kecil dan permintaan terhadapnya besar, dan sebaliknya bunga akan turun apabila jumlah uang besar tetapi permintaan sedikit (Manullang, 1983:105).

Menurut Sir Jhon Hicks bahwa tingkat bunga keseimbangan bisa dikatakan bebar-benar merupakan tingkat bunga keseimbangan bagi suatu perekonomian apabila tingkat bunga tersebut memenuhi keseimbangan di pasar dana investasi dan sekaligus keseimbangan di pasar uang, (sebagai aktiva/asset likuid). Sesuai dengan teori keynes, Hicks menyatakan bahwa tabungan tidak hanya ditentukan oleh tingkat bunga, tetapi juga oleh tingkat pendapatan. Tabungan akan naik apabila pendapatan nasional naik, dan investasi cenderung naik apabila tingkat bunga turun, dan interaksi ini bisa diturunkan kurva IS, yang menunjukkan tingkat bunga keseimbangan dipasar dana investasi pada setiap tingkat pendapatan nasional. Sedangkan kurva LM menunjukkan tingkat bunga keseimbangan yang terjadi dipasar uang pada setiap tingkat pendapatan nasional (Boediono,1995:84). 

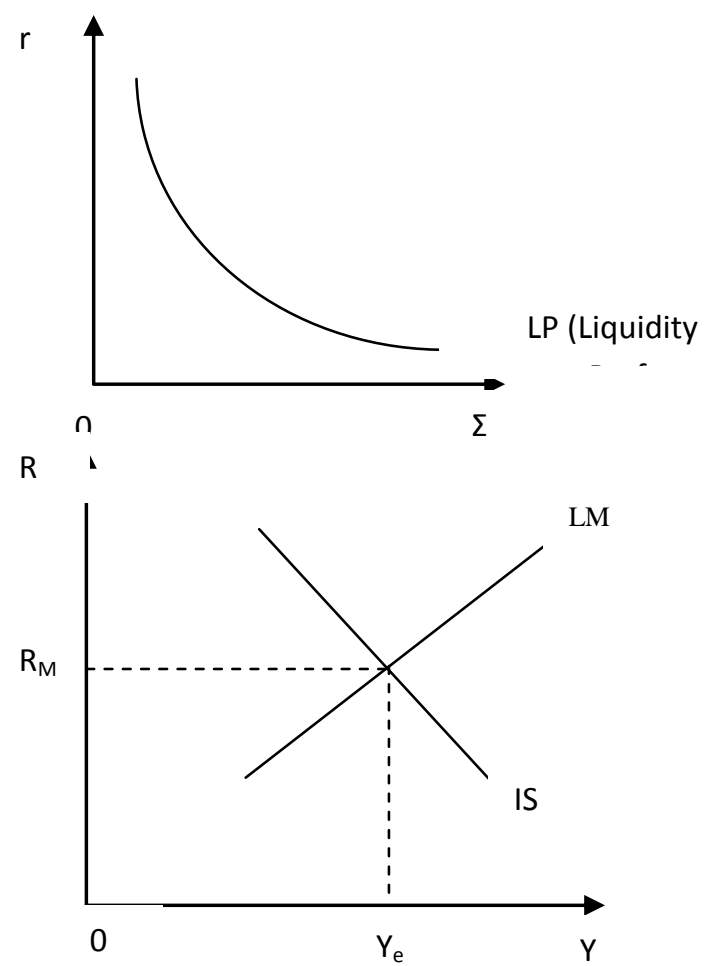

Gambar 2. Tingkat Bunga Keseimbangan (Sumber, Nopirin, 1985:113)

Jadi sintesis Hicks adalah tingkat bunga yang merupakan tingkat bunga keseimbangan dipasar investasi dan sekaligus merupakan tingkat bunga keseimbangan di pasar uang.

Perdagangan Internasional memegang peranan penting dalam sejarah pembangunan dunia ketiga. Namun kebanyakan negara-negara berkembang harus menguntungkan diri, dari pada ekspor komoditi primer bukan mineral sebagai sumber devisa. Demikian juga negara sedang berkembang sering menyandarkan diri pada ekspor bahan mentah, mesin barang modal, barang setengah jadi, dan barang konsumsi untuk mendorng peningakatan industri. Di sisi lain negara sedang berkembang permintaan terhadap barang impor telah meningkat melampui kapasitas pengahasil dari ekspor.

Hal ini menyebabkan defisit dari posisi neraca pembayaran. Sementara itu defisit pada neraca barang dan jasa (kelebihan pembayaran impor atas penerimaan ekspor barang dan jasa), sering lebih besar dari pada yang dikompensasikan oleh surplus "Neraca Modal" pada neraca pembayaran. Neraca modal merupakan bagian neraca pembayaran yang mencatat semua jual beli internasioanal atas berbagai asset. Dan perlu diketahui bahwa pembelian asset pada dasarnya adalah "impor", sedangkan penjualan asset adalah "ekspor". Neraca pembayaran menggambarkan secara menyeluruh mengenai hubungan ekonomi luar negeri yang merupakan suatu catatan sistematis mengenai semua transaksi ekonomi.

Transaksi ekonomi adalah setiap pertukaran nilai yang biasanya merupakan suatu tindakan yang menyebabkan terjadinya pengalihan barang atau jasa ekonomi. Setiap transaksi memiliki dua sisi dari sudut pandang negara asal. Kedua pandangan tersebut didefinisikan sebagai berikut; "Kredit adalah arus nilai keluar yang ditukar dengan arus nilai kenegara yang bersangkutan sebagai tukaran atau pembayaran yang harus dilunasi. Debet adalah suatu arus nilai masuk di mana penduduk dari negara tersebut harus membayar (Lindert, 1996).

Permintaan Rp ditentukan permintaan barang/jasa buatan Indonesia oleh orang Amerika. Makin banyak impor Amerika dari Indonesia makin besar kebutuhan $\mathrm{Rp}$ untuk membayar impor dari Indonesia. Transaksi impor dari Indonesia juga akan mempengaruhi penawaran US \$, karena makin besar impor dari Indonesia, maka semakin banyak US \$ harus ditukar atau ditawarkan terhadap $\mathrm{Rp}$ untuk membayar impor tersebut.

Permintaan US \$ ditentukan dari permintaan barang/jasa buatan Amerika Serikat oleh orang Indonesia. Makin banyak impor Indonesia dari Amerika Serikat, makin besar kebutuhan US \$ untuk membayar impor dari Amerika 
Serikat. Transaksi impor dari Amerika juga akan mempengaruhi penawaran $\mathrm{Rp}$, karena makin besar impor dari Amerika, maka semakin banyak Rp harus ditukar atau ditawarkan terhadap US \$ untuk membayar impor tersebut.

Berdasarkan konsep purchasing power parity (PPP), nilai barang ekspor dan impor suatu negara dipengaruhi oleh nilai tukar mata uang lokal terhadap mata uang asing. Devaluasi atau depresiasi nilai tukar mata uang lokal terhadap mata uang asing mengakibatkan nilai barang impor akan menjadi lebih mahal dan untuk barang ekspor menjadi murah. Sebaliknya apabila kebijakan revaluasi atau apresiasi dilakukan maka nilai barang impor akan menjadi lebih murah dan untuk barang ekspor akan menjadi lebih mahal (Simorangkir dan Suseno, 2004:31).

Kebijakan devaluasi atau penurunan nilai tukar mata uang lokal dapat digunakan untuk memperbaiki neraca perdagangan. Devaluasi nilai tukar mengakibatkan penurunan harga barang ekspor dan pada lanjutannya mendorong peningkatan daya saing barang-barang ekspor dan pada akhirnya dapat meningkatkan volume barangbarang ekspor.

Banyak faktor yang mempengaruhi keberhasilan devaluasi terhadap neraca perdagangan, terutama berkaitan dengan elastisitas barang impor dan ekspor. Jika elastisitas barang impor atau barang ekspor terhadap harga elastis, maka devaluasi atau depresiasi akan mendorong ekspor dan mengurangi impor. Sebaliknya, jika elastisitas barang ekspor dan impor tidak elastis, maka kebijakan devaluasi ataupun depresiasi akan sulit untuk memperbaiki neraca perdagangan. Kebijakan devaluasi dapat berhasil memperbaiki neraca perdagangan jika elastisitas barang ekspor dan impor lebih dari satu dan persyaratan ini disebut dengan MarshallLerner condition (Simorangkir dan Suseno, 2004:32).

Sifat kurs valuta asing sangat tergantung dari sifat pasar. Apabila transaksi jual beli valuta asing dapat dilakukan secara bebas dipasar, maka kurs valuta asing akan berubah-ubah sesuai dengan perubahan permintaan dan penawaran. Kebijakan pemerintah (kenaikan pengeluaran pemerintaha misalnya) akan menaikkan pendapatan dan harga. Kenaikkan pendapatan dan harga menyebabkan impor naik yang berarti naiknya permintan akan valuta asing. Akibat selanjutnya kurs valuta asing akan naik (depresiasi mata uang sendiri).

Disamping faktor-faktor ekonomi tersebut masih ada faktor nonekonomi yang menyebabkan perubahan kurs seperti faktor politik dan pysikologis, misalnya kepanikan didalam negeri akan menyebabkan kurs naik karena larinya dana keluar negeri.

Semua faktor yang didebutkan diatas akan mempengaruhi pergeseran kurva permintaan dan penawaran. Yang harus dibedakan dengan pergerakan dalam satu kurva permintaan dan penawaran itu sendiri. Secara grafik dapat dilukiskan pada gambar

Pergerakan didalam satu kurva berarti bahwa kenaikan atau penurunan kurs akan mengakibatkan penurunan atau kenaikkan jumlah valuta asing yang diminta. Sedangkan pergeseran kurva permintaan dari $\mathrm{D}_{0}$ ke $\mathrm{D}_{1}$ diakibatkan oleh kenaikan pengeluaran pemerintah, kenaikan jumlah uang yang beredar, selera masyarakat yang bergeser dari barang buatan dalam negeri menjadi barang buatan luar negeri. Makin tinggi tingkat pertumbuhan pendapatan (relatif terhadap negara lain) makin besar pula kemungkinan untuk impor yang berarti makin besar pula permintaan akan valuta asing. 
Menurut Hady (1999:45) teori IRP (Interest Rate Parity) mengatakan bahwa perbedaan tingkat suku bunga pada International Money Market akan cenderung sama dengan forward rate premium atau pun discoun. Dengan kata lain, berdasarkan IRP akan dapat ditentukan berapa perubahan kurs forward atau forward rate (FR) dibandingkan dengan spot rate (SR) bila terdapat perbedaan tingkat bunga antara home country dengan foreign country.

Menurut Krugman (1992:118) bahwa kurs terbentuk oleh suku bunga dan perkiraan-perkiraan atau harapan untuk masa mendatang. Namun untuk memahami sepenuhnya gerakan-gerakan kurs dalam jangka panjang, kita harus memperluas model kita kedua arah. Pertama kita harus melengkapi penelaahan terhadap keterkaitan antara kebijakan-kebijakan moneter, inflasi, suku bunga dan kurs. Kedua, kita harus menyoroti sejumlah faktor selain dari penawaran dan permintaan uang misalnya, berbagai pergeseran permintaan pasar akan barang dan jasa yang turut mempengaruhi kurs.

Instrumen tingkat suku bunga dalam jangka panjang, menyebabkan nilai tukar rupiah terdepresiasi. Selain tidak efektif, menaikkan suku bunga berdasarkan pengalaman ekonomi yang terjadi di Indonesia, justru mendorong peningkatan laju inflasi. Berbagai studi juga mengungkapkan bahwa tingkat suku bunga tidak begitu berpengaruh besar pada perubahan kurs rupiah. Menurut Basri (2002:87) ada beberapa hal yang perlu mendapat perhatian khusus dalam mencapai target makroekonomi yang telah ditetapkan adalah intervensi politik terhadap BI yang kemudian mempengaruhi kebijakan moneter atau BI sendiri yang berpolitik. Hal ini bisa menyebabkan melesetnya target inflasi yang pada giliranya mepengaruhi kurs rupiah, suku bunga, dan perubahan ekonomi serta pemuliahan ekonomi secara keseluruhan.

Menurut Basri (2002:84), Kebijkan moneter lebih berperan dalam menstimulasi pemulihan ekonomi. Kebijakan moneter yang efektif menjajikan tercapinya inflasi yang rendah, stabilitas kurs dan suku bunga.

Dalam perekonomian terbuka dengan arus lalu lintas modal yang bebas, peningkatan suku bunga akan meperkuat nilai tukar karena terjadi pemasukan modal dari luar negeri (kecuali ada faktor lain yang kurang dapat merangsang investasi, instabilitasi politik). Apabila semakin tinggi tingkat suku bunga maka kurs rupiah akan terapresiasi.

Secara teoritis, meningkatnya
inflasi akan mengakibatkan
terdepresiasinya kurs rupiah dan
meningkatnya tingkat suku bunga akan
mengakibatkan kenaikan nilai tukar
rupiah terhadap dollar. Suku bunga yang
tinggi memang tidak memberikan iklim
yang kondusif bagi pemulihan ekonomi.
Sekalipun kurs rupiah telah mengalami
penguatan.
penguatan. 


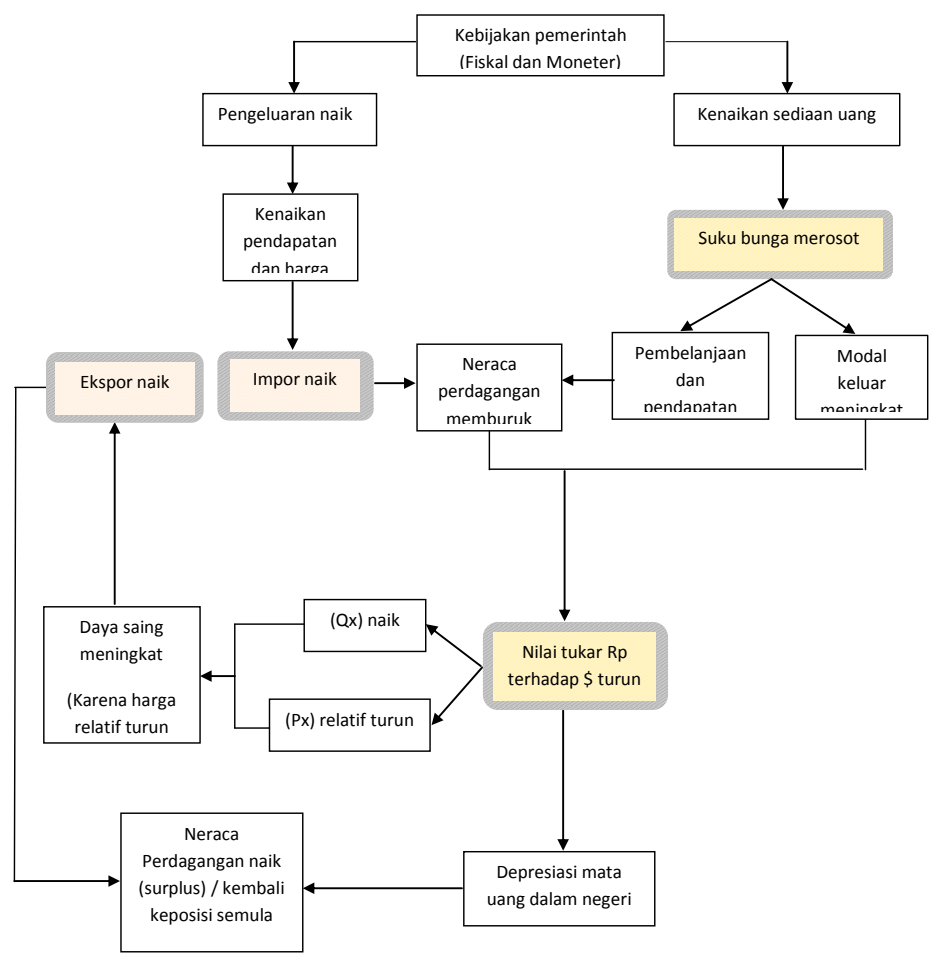

Gambar 3. Konsep Gabungan Nilai Tukar, Tingkat Suku Bunga, dan Ekspor-Impor

\section{METODE PENELITIAN}

Alat analisis penelitian yang digunakan untuk mengetahui hubungan antara kejutan nilai tukar dengan variabel-variabel penelitian dan hipotesis yang telah disusun berdasarkan teori. Penjelasan mengenai alat analisis penelitian ini mengemukakan cara penelitian yang digunakan untuk estimasi model yang dikemukakakan dalam penelitian ini. Pembahasan alat analisis penelitian ini meliputi permasalahan statistik berkaitan dengan estimasi model runtut waktu. Penelitian ini menggunakan data time series yang mempunyai karakteristik khusus dalam analisisnya. Permasalahan yang akan dikemukakan meliputi stasionaritas data dan pengujiannya. Dengan memperhatikan kerangka pikir diatas maka penelitian ini mengunakan analisis regresi berganda.

Menurut Sanusi (2003:121) untuk mengetahui pengaruh tingkat suku bunga dan ekspor impor terhadap nilai tukar rupiah, digunakan analisis regresi linier berganda. Regresi ini dilakukan atas satu variabel terikat terhadap dua variabel bebas. Hal ini bertujuan untuk mengetahui pengaruh antara variabel bebas secara keseluruhan terhadap variabel terikat.

Secara sistematik persamaan tersebut dapat dituliskan dengan:

$\mathrm{Y}=\mathrm{a}+\mathrm{b}_{1} \mathrm{X}_{1}+\mathrm{b}_{2} \mathrm{X}_{2}+\mathrm{ei}$

Dimana, $Y=$ Besarnya nilai tukar rupiah; $\mathrm{X}_{1}=$ Besarnya tingkat suku bunga SBI; $X_{2}=$ Besarnya net ekspor impor; $\mathrm{a}=$ Konstanta; $\mathrm{b}_{1}, \mathrm{~b}_{2}=$ Koefisien regresi; ei $=$ Variabel pengganggu yang mewakili semua faktor-faktor lain tetapi tidak dimasukan dalam model.

Langkah selanjutnya setelah melakukan regresi adalah menguji hipotesis yang telah dibuat sebelumnya. Adapun uji hipotesis ini ada dua macam, yaitu: uji parsial (uji t) dan uji serentak (uji F). 
Uji hipotesis (Uji t), adalah untuk menguji koefisien regresi secara parsial atau mengetahui masing-masing variabel indefenden terhadap variabel defenden. Uji ini dilakukan dengan maksud untuk mengetahui pengaruh variabel bebas secara parsial terhadap variabel terikatnya

Uji hipotesa dua arah memiliki dua arah penolakan Ho yaitu daerah positif (di sebelah kanan $\mu$ ) dan negatif (di sebelah kiri $\mu$ ). Jika letak nilai t statistik berada di sebelah kiri di daerah $\mathrm{t}$ krtitis negatif atau sebelah kanan daerah positif maka Ho ditolak (signifikan). Namun apabila $\mathrm{t}$ statistik berada dalam $\mathrm{t}$ kritis (negatif-positif), maka Ho diterima (tidak signifikan) Hipotesa yang disusun adalah sebagai berikut:

Ho ; $\beta=0$, berarti tidak ada pengaruh secara parsial antara variabel bebas (Xi) terhadap variabel terikat (Yi).

$\mathrm{Hi}=\beta \neq 0$ berarti ada pengaruh secara parsial antara variabel bebas (Xi) terhadap variabel terikat (Yi).

Dengan ketentuan:

Uji dua arah wilayah nilai kritis ada dua yaitu negatif dan positif, sehingga agar lebih mudah dalam memahami ketentuan berikut, nilai $\mathrm{t}$ hitung akan dilihat nilai mutlaknya (positif). Jika t hitung $>\mathrm{t}$ tabel, maka Ho ditolak dan Hi diterima, berarti pengaruh variabel bebas (Xi) dengan variabel terikat (Yi) adalah signifikan. Jika $\mathrm{t}$ hitung < t tabel, maka Ho diterima dan Hi ditolak, berarti pengaruh variabel bebas (Xi) dengan variabel terikat (Yi) adalah tidak signifikan.

Uji seluruh koefisien regresi secara serempak sering disebut dengan uji model. Oleh karena nilai $F$ hitung berhubungan erat dengan nilai koefisien determinan $\left(\mathrm{R}^{2}\right)$, maka pada saat melakukan uji $\mathrm{F}$ sesungguhnya menguji signifikansi koefisien determinan $\left(\mathrm{R}^{2}\right)$. Uji $F$ yang signifikan menunjukkan bahwa variabel-variabel tergantung dijelaskan sekian persen oleh variabel bebas secara bersama-sama adalah benar-benar nyata dan bukan terjadi karena kebetulan.

Dengan kata lain, berapa persen variabel tergantung dijelaskan oleh seluruh variabel bebas secara serempak (bersama-sama), dijawab oleh koefisien determinasi $\left(\mathrm{R}^{2}\right)$, sedangkan signifikan atau tidak yang sekian persen itu dijawab oleh uji F. Berdasarkan ini, maka nilai koefisien determinan $\left(R^{2}\right)$ dan uji $F$ menentukan baik tidaknya model yang digunakan. Makin tinggi nilai koefisien determinan $\left(\mathrm{R}^{2}\right)$ dan signifikan, maka makin baik model tersebut.

Hipotesis yang digunakan dalam uji ini yaitu. Jika $F$ statistik > F kritis, maka Ho ditolak dan Hi diterima, berarti pengaruh variabel bebas (Xi) terhadap variabel terikat (Yi) adalah signifikan. Jika $\mathrm{F}$ statistik < F kritis, maka Ho diterima dan Hi ditolak, berarti pengaruh variabel bebas (Xi) terhadap variabel terikat (Yi) adalah tidak signifikan

$\mathrm{R}^{2}$ menjelaskan proporsi variasi dalam varabel tergantung (Y) yang dijelaskan oleh variabel bebas (lebih dari satu variabel : $\mathrm{X}_{1} ; 1=1=1,2,3 \ldots . \mathrm{k}$ ) secara bersam-sama $\mathrm{R}$ adalahkoefisien korelasi majemuk yang mengukur tingkat hubungan antara variabel tergantung (Y) dengan semua variabel bebas yang menjelaskan secara bersamsama, dan nilainya selalu positif. Nilai $\mathrm{R}^{2}$ digunakan untuk melihat kemampuan model menerangkan variasi perubahanperubahan variabel bebas. Oleh karena itu mempergunakan Adjusted $R$ Square $\left(\mathrm{R}^{2}\right)$ yang sudah memperhitungkan derajat kebebasan (dgree of freedom).

Adapun $\mathrm{R}^{2}$ tersebut dapat dirumuskan sebagai berikut:

$\mathrm{R}^{2}=1-\left(1-\mathrm{r}^{2}\right)^{\frac{n-1}{N-k_{-1}}}$ 
Koefisien determinan $\left(\mathrm{R}^{2}\right)$ maupun koefisien determinan yang disesuaikan $\left(\mathrm{R}^{-2}\right)$ menunjukan kemampuan model (variabel penjelas) dalam menjelaskan variabel- variabel terikat. Apabila nilai $\mathrm{R}^{2}$ besarnya antara $0<\mathrm{R}^{2}$, dimana semakin mendekati 1 maka dapat dinyatakan model semakin baik dengan asumsi tidak terjadi regresi lancung.

\section{PEMBAHASAN}

Tabel 1. Hasil Regresi

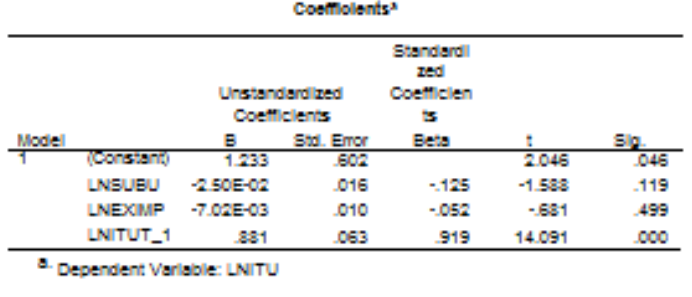

Dengan berdasarkan hasil perhitungan regresi pada tabel diatas didapatkan suatu persamaan garis regresi sebagai berikut:

Ln Nilai Tukar $=\operatorname{Ln} \beta o+\beta_{1}$ LnSubu $(\mathrm{X} 1)+\beta_{2}$ LnEximp $_{2}$ $+\beta_{3}$ Ln Nitut_1 $1_{3}+\mathrm{E}$

LnNitu $=$ Ln $1.233-0.025$ Ln Subu 0.00702 Ln eximp + 0.881 LnNitut_1 +e

$\mathrm{a}($ intercept $)=1.233$ berarti jika variabel suku bunga dan nilai ekspor sama dengan nol, maka nilai tukar rupiah terhadap US \$ sama dengan 1.233.

Nilai koefisien regresi sebesar Ln -0.025 yang berarti menunjukkan pengaruh variabel Suku Bunga terhadap variabel nilai tukar rupiah terhadap US \$. Yaitu bahwa dengan adanya perubahan suku bunga sebesar satu \%, maka nilai tukar rupiah terhadap US \$ akan menurun sebesar 0.025 .

Nilai koefisien regresi sebesar Ln -0.00702 yang berarti menunjukkan pengaruh variabel Nilai Eximp terhadap variabel nilai tukar rupiah terhadap US \$. Yaitu bahwa dengan adanya peningkatan Nilai Eximp sebesar satu \%
, maka nilai tukar rupiah terhadap US \$ akan menurun sebesar -0.00702 .

Nilai koefisien regresi sebesar Ln 0.881 yang berarti menunjukkan pengaruh variabel nilai tukar rupiah terhadap US \$ lag 1 terhadap variabel nilai tukar rupiah terhadap US \$ tahun ini. Yaitu bahwa dengan adanya peningkatan nilai tukar rupiah terhadap US \$ lag 1 sebesar satu \%, maka nilai tukar rupiah terhadap US \$ saat ini akan meningkat sebesar 0.881 .

Tabel 2. Nilai R-Square

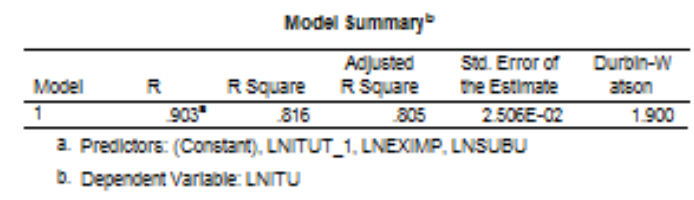

Berdasarkan pada hasil dari analisa regresi berganda dari masing-masing variabel tingkat suku bunga dan nilai ekspor terhadap nilai tukar rupiah US \$ memiliki korelasi ganda (Multiple R) sebesar 0.903. Angka ini menunjukkan kuatnya hubungan antara seluruh variabel bebas dengan variabel terikat. Angka tersebut mendekati 1, berarti hubungan antara variabel bebas dengan variabel terikat sangat erat.

Koefisien Determinasi $\mathrm{R}^{2}$ sebesar 0.816. Dari besaran $\mathrm{R}^{2}$ tersebut dapat disimpulkan bahwa variabel suku bunga dan nilai ekspor menjelaskan keragaman dari dependent variabel Nilai Tukar Rupiah terhadap US \$ yaitu sebesar 82 $\%$. Sedangkan sisanya sebesar $18 \%$ dijelaskan oleh variabel lain yang tidak dimasukkan ke dalam model persamaan.

Guna melihat apakah variabel independen secara bersama-sama mempengaruhi variabel dependent secara nyata atau tidak, dengan menggunakan Uji $F$ yaitu dengan cara membandingkan nilai $F_{\text {hitung dengan }}$ $\mathrm{F}_{\text {tabel. }}$

Tabel 3. Nilai $F_{\text {hitung }}$ 


\begin{tabular}{|c|c|c|c|c|c|c|}
\hline \multicolumn{7}{|c|}{ ANOVA ${ }^{b}$} \\
\hline Model & & $\begin{array}{l}\text { Sum of } \\
\text { Squares }\end{array}$ & df & Mean Square & $\mathrm{F}$ & \\
\hline \multirow[t]{3}{*}{1} & Regression & .139 & 3 & $4.643 \mathrm{E}-02$ & 73.946 & $.000^{\mathrm{a}}$ \\
\hline & Residual & 3.139E-02 & 50 & $6.278 \mathrm{E}-04$ & & \\
\hline & Total & .171 & 53 & & & \\
\hline
\end{tabular}

Dengan pengujian uji $\mathrm{F}$ diperoleh nilai $F_{\text {hitung }}$ sebesar 73.946 , sedangkan $\mathrm{F}_{\text {tabel }}$ pada taraf nyata $5 \%$ menunjukkan nilai sebesar 2.76, karena $F_{\text {hitung }}>F_{\text {tabel }}$ maka hipotesis nol (Ho) di tolak dan Hipotesa alternatif (Hi) diterima. Hal ini menunjukkan bahwa ketiga variabel independent secara bersama-sama mempengaruhi nilai tukar rupiah terhadap US \$.

Dengan demikian hipotesa yang menyatakan nilai ekspor-impor, dan tingkat suku bunga SBI secara simultan berpengaruh positif terhadap nilai tukar di Indonesia dapat diterima.

Untuk mengetahui sejauh mana kebenaran koefisien Regresi untuk variabel Tingkat Suku Bunga digunakan uji $\mathrm{t}$, dengan ketentuan sebagai berikut:

Ho : $\beta 1=0$ : artinya tidak ada pengaruh dari variabel Tingkat Suku Bunga terhadap variabel Nilai Tukar Rupiah terhadap US \$

$\mathrm{Hi}: \beta 1 \neq 0$ : artinya ada pengaruh dari variabel Tingkat Suku Bunga terhadap variabel Nilai Tukar Rupiah terhadap US \$.

Dengan menggunakan test dua arah, derajat bebas 49 dan taraf nyata $5 \%$, diperoleh nilai $t_{\text {tabel }}$ sebesar 2.0096. Sedangkan dengan pengujian statistik diperoleh $t_{\text {hitung }}$ sebesar -1.588 , karena nilai $t_{\text {hitung }}<t_{\text {tabel }}$, maka Ho ditolak dan $\mathrm{Hi}$ diterima. Dengan demikian dapat diambil kesimpulan bahwa variabel tingkat suku bunga adalah tidak signifikan pada taraf nyata $\alpha=5 \%$ dengan tingkat kepercayaan $95 \%$.

Untuk mengetahui sejauh mana kebenaran koefisien Regresi untuk variabel Nilai Ekspor Import digunakan uji t, dengan ketentuan sebagai berikut:
Ho : $\beta 2=0:$ artinya tidak ada pengaruh dari variabel Nilai Ekspor Import terhadap variabel Nilai Tukar Rupiah terhadap US \$

Hi : $\beta 2 \neq 0$ : artinya ada pengaruh dari variabel Nilai Ekspor Import terhadap variabel Nilai Tukar Rupiah terhadap US \$.

Dengan menggunakan test dua arah, derajat bebas 49 dan taraf nyata $5 \%$, diperoleh nilai $t_{\text {tabel }}$ sebesar 2.0096 . Sedangkan dengan pengujian statistik diperoleh $t_{\text {hitung }}$ sebesar -0.681 , karena nilai $t_{\text {hitung }}<\mathrm{t}_{\text {tabel }}$, maka Ho ditolak dan Hi diterima. Dengan demikian dapat diambil kesimpulan bahwa variabel Nilai Ekspor Import adalah tidak signifikan pada taraf nyata $\alpha=5 \%$ dengan tingkat kepercayaan $95 \%$.

Untuk mengetahui sejauh mana kebenaran koefisien Regresi untuk variabel Nilai Ekspor Import digunakan uji t, dengan ketentuan sebagai berikut:

Ho: $\beta 3=0$ : artinya tidak ada pengaruh dari variabel Nilai Tukar Rupiah terhadap US \$ Lag 1 terhadap variabel Nilai Tukar Rupiah terhadap US \$.

Hi : $\beta 3 \neq 0$ : artinya ada pengaruh dari variabel Nilai Tukar Rupiah terhadap US \$ Lag 1 terhadap variabel Nilai Tukar Rupiah terhadap US \$.

Dengan menggunakan test dua arah, derajat bebas 49 dan taraf nyata $5 \%$, diperoleh nilai $t_{\text {tabel }}$ sebesar 2.0096 . Sedangkan dengan pengujian statistik diperoleh $\mathrm{t}_{\text {hitung }}$ sebesar 14.091, karena nilai $t_{\text {hitung }}<t_{\text {tabel }}$, maka Ho ditolak dan Hi diterima. Dengan demikian dapat diambil kesimpulan bahwa variabel Nilai Tukar Rupiah terhadap US \$ Lag 1 adalah signifikan pada taraf nyata $\alpha=5$ $\%$ dengan tingkat kepercayaan $95 \%$.

Dengan berdasar pada analisis empiris di atas, telah diketahui bahwa 
variabel Tingkat Suku Bunga dan Nilai Ekspor Import mempunyai pengaruh yang cukup berarti terhadap Nilai Tukar Rupiah terhadap US\$ untuk kurun waktu 2002 - 2006.

Pembahasan dibawah ini akan menjelaskan hubungan antara tujuan penelitian dengan hasil penelitan. Di depan telah dijelaskan bahwa tujuan penelitian adalah untuk mengetahui besarnya pengaruh Tingkat Suku Bunga dan Nilai Ekspor Impor terhadap nilai tukar rupiah oleh dolar untuk kurun waktu tahun 2002 - 2006.

Berdasar pada hasil perhitungan regresi diperoleh nilai koefisien regresi yang negatif antara Tingkat suku bunga dengan Nilai Tukar Rupiah terhadap US \$ untuk kurun waktu 2002 - 2006.

Uji t menunjukkan bahwa t hitung $<\mathrm{t}$ tabel, hal ini menyatakan bahwa Tingkat Suku Bunga tidak mempunyai pengaruh yang berarti. Sedangkan angka koefisien regresi dalam perhitungan menunjukkan pengaruh variabel tingkat suku bunga terhadap nilai tukar rupiah terhadap US \$. Hal ini menunjukkan bahwa dengan tiap terjadinya peningkatan nilai tingkat suku bunga sebesar $1 \%$ akan menurunkan volume nilai tukar rupiah terhadap US \$ sebesar 0.00702

Perkembangan tingkat suku bunga pada tahun 2002 terus menerus mengalami penurunan dari rata-rata pada bulan Januari tahun 2002 sebesar $17,09 \%$ menjadi $12,99 \%$ pada bulan Desember. Penurunan ini diakibatkan adanya inflasi pada tahun 2002 yang mencapai $11 \%$. Penurunan suku bunga juga terjadi pada tahun 2003 dan 2004, di mana tahun 2003 mengalami penurunan sebesar $4,68 \%$ dari tahun 2002 dan pada tahun 2004 mengalami penurunan sebesar $0,88 \%$ dari tahun 2003.

Berdasar pada hasil perhitungan regresi diperoleh nilai koefisien regresi yang negatif antara Nilai Ekspor Import dengan Nilai Tukar Rupiah terhadap US \$ untuk kurun waktu 2002 - 2006.

Uji t menunjukkan bahwa t hitung $<$ t tabel, hal ini menyatakan bahwa Nilai Eksport Import tidak mempunyai pengaruh yang berarti. Sedangkan angka koefisien regresi dalam perhitungan menunjukkan pengaruh variabel nilai eksport import terhadap nilai tukar rupiah terhadap US \$. Hal ini menunjukkan bahwa dengan tiap terjadinya peningkatan nilai ekspor import sebesar $1 \%$ akan menurunkan volume nilai tukar rupiah terhadap US \$ sebesar 0.025 .

Nilai Eskport Impor merupakan selisih antara nilai eksport baik Migas dan Non Migas yang terjadi dalam kurun waktu tertentu.. Dengan adanya Nilai Eskpor Non Migas dan Migas yang cukup tinggi khususnya pada Hasil Hutang dan Laut antara lain Plywood, Blockboard, Chip Wood, Moulding, Kayu Laminating meliputi Ikan Segar, Ikan Kerapu, Lobster, Kepiting dan Udang Beku pada tahun 2006 mencapai 11.232.103,8 US\$.

Berdasar pada hasil perhitungan regresi diperoleh nilai koefisien regresi yang positif antara Nilai Tukar Rupiah terhadap US\$ Lag 1 dengan Nilai Tukar Rupiah terhadap US\$ Tahun ini untuk kurun waktu 2002- 2006.

Uji t menunjukkan bahwa t hitung $>$ t tabel, hal ini menyatakan bahwa Nilai Tukar Rupiah terhadap US\$ Lag 1 mempunyai pengaruh yang cukup berarti. Sedangkan angka koefisien regresi dalam perhitungan menunjukkan pengaruh variabel bebas terhadap variabel terikat. Hal ini menunjukkan bahwa dengan tiap terjadinya peningkatan Nilai Tukar Rupiah terhadap US \$ lag 1 sebesar $1 \%$ akan meningkatkan Nilai Tukar Rupiah terhadap US\$ Tahun ini 0.881 . 
Nilai tukar merupakan nilai atau harga tukar suatu mata uang negara lain yang ditetapkan atau terjadi dalam lalu lintas perdagangan dan moneter suatu negara. Nilai tukar ini akan sangat mempengaruhi nilai ekspor barang dan jasa yang diproduksi oleh suatu daerah ataupun negara. Dengan nilai tukar nilai tukar yang semakin tinggi akan memberikan keuntungan yang lebih besar bagi produsen dalam negeri. Dalam hal ini para pengahsil produk atau jasa akan beranggapan lebih mendapatkan keuntungan yang lebih besar bila melakukan penjualan ke luar negeri dari pada penjualan di dalam negeri. Dengan demikian setiap produsen dalam negeri akan semakin terpacu untuk melakukan penjualan barang dan jasanya keluar negeri, dengan adanya fenomena tersebut akan semakin besar pula devisa yang diterima negara melalui ekspor.

\section{PENUTUP}

Secara umum dari hasil penelitian ini dapat diambil kesimpulan, bahwa terjadi peningkatan ekspor dari tahun 2002 hingga tahun 2006, penigkatan ini sangat signifikan khususnya pada ekspor non migas sedangkan ekspor migas mengalami penurunan pada tahun 2003 dan 2005. Perkembangan nilai tingkat suku bunga pada periode Januari tahun 2002 sampai dengan Juni tahun 2005 mengalami penurunan yang sangat tinggi. Hal tersebut dikarenakan keadaan sosial politik Indonesia saat itu dalam kondisi yang kurang stabil. Beberapa kerusuhan yang terjadi di berbagai tempat mengakibatkan investor enggan menanamkan modalnya di Indonesia, karena keamanan yang tidak mendukung. Terjadinya inflasi pada tahun 2002 yang mencapai $11 \%$ membuat pertumbuhan ekonomi menambah lesu hingga pertumbuhan ekonomi mencapai 3,2\%-3,5\% jauh dari target awal pemerintah. Tingkat suku bunga yang terus menerus mengalami penurunan hingga mencapai rata-rata pada awal periode I sebesar $15,17 \%$ dan terus turun hingga mencapai level 12,99\% pada akhir tahun 2002.

Apresiasi nilai tukar rupiah terhadap dolar cenderung menurun, yang disertai suku bunga simpanan perbankan yang cenderung menguat pada tahun pada pertengahan tahun 2004 dan cenderung melemah kembali hingga akhir tahun 2005. Tetapi berangsurangsur menguat hingga kahir tahun 2006.

Sedangkan pengaruh nilai eksporimpor, dan tingkat suku bunga SBI terhadap nilai tukar di Indonesia dapat di jelaskan sebagai berikut 1) Tingkat Suku Bunga tidak mempunyai pengaruh yang berarti terhadap nilai tukar rupiah terhadap US \$. Hal ini dapat diartikan bahwa dengan tiap terjadinya peningkatan nilai tingkat suku bunga akan diikuti penurunan volume nilai tukar rupiah terhadap US \$. 2) Nilai Eksport Import tidak mempunyai pengaruh yang berarti. terhadap nilai tukar rupiah terhadap US \$. Hal ini dapat diartikan bahwa setiap terjadinya peningkatan nilai eksport import akan menurunkan volume nilai tukar rupiah terhadap US \$. 3)Sedangkan Nilai Tukar Rupiah terhadap US\$ Lag 1 mempunyai pengaruh yang cukup berarti terhadap Nilai Tukar Rupiah terhadap US\$ saat ini. Hal ini berarti setiap terjadinya peningkatan Nilai Tukar Rupiah terhadap US \$ lag 1 akan diikuti peningkatan Nilai Tukar Rupiah terhadap US\$ Tahun ini.

\section{DAFTAR PUSTAKA}

Ahmad Jamli, $1996 . \quad \begin{array}{r}\text { Keungan } \\ \text { Internasioanal. } \\ \text { BPFE. }\end{array}$
Yogyakarta:


Boediono,1990. Ekonomi Moneter. Edisi Tiga. Yogyakarta: BPFE

H.Lindert, Peter. 1994. Ekonomi Internasional, Edisi Kesembilan. JAKARTA. PT. BUMI AKSARA.

Imam Ghazali, 2006. Analisis Multivariate Lanjutan. Semarang. UNDIP.

Krugman, Paul \& Obstfeld, M. 1996. Ekonomi Internasional, Teori Dan Kebijakan; Jilid 2. Jakarta. PT. Rajawali Pers.

Kuncoro, Mudrajat, dkk. 1997. Management keuangan Internasional, Pengantar Ekonomi Bisnis Dan Global. Yogyakarta. BPFE.

Levi, Maurice. D. 1996. Manajemen Keuangan Internasional Edisi Pertama, Mc-Graw Hill-Andi. Yogyakarta.

Mudrajad Kuncoro, dkk. 1997. Ekonomi Industri-Teori, Kebijakan Dan Study Empiris Di Indonesia. Yogyakarta.Widya Sarana Informatika.

Mankiw, N. Gregory, 2000. Teori makro Ekonomi edisi IV. Jakarta. Erlangga.

Nopirin, 1991. Ekonomi Internasional, Edisi Keduat, Yogyakarta, BPFE Yogyakarta.

Nopirin, 1992. Ekonomi I, Edisi Keempat, Yogyakarta, BPFE Yogyakarta.
Nopirin, 1993. Ekonomi Moneter II, Edisi Keempat, Yogyakarta, BPFE - Yogyakarta.

Salvatore, Dominick. 1997. Ekonomi Internasional, Edisi Kedua, Jakarta. Erlangga.

Syamsul Hadi, 2007. Kejutan Perubahan Nilai Tukar Riil terhadap Inflasi, Pertumbuhan Output dan Pertumbuhan Neraca Transaksi Berjalan di Indonesia. Proposal penelitian pengembangan IPTEKS. Tidak di publikasikan. 